\title{
Food Safety and Produce Operations: What Is the Future?
}

\author{
L.R. Howard ${ }^{\mathbf{1}}$ and A.R. Gonzalez \\ Institute of Food Science and Engineering, University of Arkansas, 272 Young Avenue, Fayetteville, AR 72704
}

Pathogen outbreaks associated with fresh and fresh-cut produce have recently received much attention. Excellent reviews on pathogenic microorganisms associated with fresh (Beuchat, 1995; Tauxe et al., 1997) and minimally processed (Brackett, 1994; Nguyen-the and Carlin, 1994) fruits and vegetables are available. Although the number of outbreaks of illness associated with produce is rare, greater attention to quality assurance systems, such as good agricultural practices (GAPs; Beuchat and Hoon Ryu, 1997; U.S. Food and Drug Administration, 1998); good manufacturing practices (GMPs; Moberg, 1989); standard sanitation operating procedures (SSOPs; Corlett, 1998); and hazard analysis critical control point (HACCP) programs (National Advisory Committee on Microbiological Criteria for Foods, 1998) are needed to ensure the safety of domestic and imported produce and fresh-cut products.

Although HACCP programs are not currently mandatory for growers of fresh produce, several buyers are requiring that growers implement HACCP plans to ensure food safety practices for growing, harvesting, postharvest handling, and transporting fresh produce (Barth, personal communication; Mudahar, personal communication). Cider processors will be required to adopt HACCP plans by 1999 because of recent outbreaks of Escherichia coli (Besser et al., 1993), and the U.S. Food and Drug Administration (FDA) is currently writing a proposal that will require growers of alfalfa (Medicago sativa L.), and bean (Phaseolus vulgaris L.) and radish (Raphanus sativus L.) sprouts to implement some form of HACCP because of recent pathogen outbreaks associated with these products (Itoh et al., 1998; Jaquette et al., 1996; O’Mahony et al., 1990).

\section{HAZARD ANALYSIS CRITICAL CONTROL POINT PRINCIPLES}

The HACCP system is a logical, scientific system that can control safety problems in food production. It is defined as "a systematic

Received for publication 7 Feb 2000. Accepted for publication 8 June 2000. South Carolina Agricultural Experiment Station Technical Contribution No. 4459. The cost of publishing this paper was defrayed in part by the payment of page charges. Under postal regulations, this paper therefore must be hereby marked advertisement solely to indicate this fact.

${ }^{1}$ To whom reprint requests should be addressed. E-mail address: lukeh@comp.uark.edu approach to the identification, evaluation, and control of food safety hazards, from raw material production and procurement to distribution and consumption of the finished product" (National Advisory Committee on Microbiological Criteria for Foods, 1998). Industry has been proactive in putting together HACCP plans for fresh-cut produce (Zagory, 1996), and has worked in cooperation with the FDA in designing a Guide to Minimize Microbial Food Safety Hazards for Fresh Fruits and Vegetables (U.S. Food and Drug Administration, 1998). Although more science-based research on factors affecting pathogen contamination of produce is needed prior to HACCP implementation, growers should understand HACCP and GAP principles, and how they may be used to reduce the risk of foodborne pathogens associated with fresh produce.

The HACCP plans for fresh-cut vegetables are well established, have been used successfully by processors for many years, and are based on the same seven principles and risk assignment categories common to meat, poultry, and seafood control. These principles are conducted in the following order: 1) conduct a hazard analysis; 2) determine the critical control points; 3) establish the critical limits; 4) establish monitoring procedures; 5) establish corrective actions; 6) establish verification procedures; and 7) establish record-keeping and documentation procedures. Prerequisite programs for GMPs and SSOPs are typically addressed prior to development of HACCP plans in order to establish sanitary and hygienic practices in the processing environment. The goal of HACCP systems is to identify critical control points for biological, physical, and microbiological hazards from raw material production, procurement, and handling, to manufacturing, distribution, and consumption of the finished product. A critical control point is defined as "a step at which control can be applied and is essential to prevent or eliminate a food safety hazard or reduce it to an acceptable level" (National Advisory Committee on Microbiological Criteria for Foods, 1998). Potential hazards during production of raw product for fresh-cut processing are listed in Table 1 , and a model HACCP plan for fresh-cut produce is illustrated in Table 2. Excellent references are available for more detailed information on GMPs (Moberg, 1989), SSOPs (Corlett, 1998) and HACCP plan development (Corlett, 1998; National Advisory Committee on Microbiological Criteria for Foods, 1998; Stevenson and Bernard, 1995). Note that HACCP plans for fresh-cut produce do not contain a sterilization step to destroy pathogenic microorganisms. The major

Table 1. Potential hazards during production of raw product for fresh-cut processing. ${ }^{2}$

\begin{tabular}{|c|c|c|c|}
\hline $\begin{array}{l}\text { Production } \\
\text { factor }\end{array}$ & $\begin{array}{c}\begin{array}{c}\text { Potential } \\
\text { hazard }\end{array} \\
\end{array}$ & Prevention & Documentation \\
\hline Land use & $\begin{array}{l}\text { (a) Fecal contamination (source of } \\
\text { pathogens) from animals } \\
\text { (b) Toxic pesticide residues in soil }\end{array}$ & $\begin{array}{l}\text { No grazing animals or feedlots on/near } \\
\text { production land } \\
\text { Review pesticide history for plant-back } \\
\text { restrictions. }\end{array}$ & $\begin{array}{l}\text { Grower certification of no recent } \\
\text { animal husbandry on land used } \\
\text { Pesticide selection/application records }\end{array}$ \\
\hline Fertilizers & $\begin{array}{l}\text { (a) Pathogenic bacteria from organic } \\
\text { fertilizers } \\
\text { (b) Heavy metal toxicity from sewage } \\
\text { sludge }\end{array}$ & $\begin{array}{l}\text { Use inorganic fertilizer. } \\
\text { Use certified organic fertilizers or } \\
\text { tested and approved sludge. }\end{array}$ & $\begin{array}{l}\text { Certified test results } \\
\text { Certified test results }\end{array}$ \\
\hline Irrigation water & $\begin{array}{l}\text { (a) Pathogenic bacteria from surface water } \\
\text { in groundwater } \\
\text { (b) Heavy metal/pesticide residues }\end{array}$ & $\begin{array}{l}\text { Test/monitor water supply. } \\
\text { Test/monitor water supply. }\end{array}$ & $\begin{array}{l}\text { Water test results } \\
\text { Water test results }\end{array}$ \\
\hline Pesticide use & Illegal/hazardous residues on product & $\begin{array}{l}\text { Employ only professional, licensed } \\
\text { applicators and monitor pesticide use. }\end{array}$ & $\begin{array}{l}\text { Examine applicator records; test for } \\
\text { residues. }\end{array}$ \\
\hline Hand harvesting & Fecal contamination of product & $\begin{array}{l}\text { Field worker personal hygiene; field } \\
\text { washing/sanitizing facilities available }\end{array}$ & Training programs on worker hygiene \\
\hline Field containers & Soil- and human-borne pathogens & $\begin{array}{l}\text { Use plastic bins; clean/sanitize all } \\
\text { containers. }\end{array}$ & Field sanitation records \\
\hline Country of origin & Pathogenic bacteria on product & $\begin{array}{l}\text { Use approved cultivation methods, water } \\
\text { supplies, and harvesting practices. }\end{array}$ & Supplier certificate of produce safety \\
\hline
\end{tabular}


Table 2. International Fresh-cut Produce Association model hazard analysis critical control point plan for shredded lettuce. ${ }^{\text {z,y }}$

\begin{tabular}{|c|c|c|c|c|c|c|c|c|}
\hline Flow process & $\begin{array}{l}\text { Hazard } \\
\text { category }\end{array}$ & $\begin{array}{c}\text { Critical } \\
\text { control point }\end{array}$ & $\begin{array}{l}\text { Critical } \\
\text { limit }\end{array}$ & Monitoring & Frequency & $\begin{array}{c}\text { Corrective } \\
\text { preventive action }\end{array}$ & $\begin{array}{l}\text { Record } \\
\text { keeping }\end{array}$ & Verification \\
\hline $\begin{array}{l}\text { Raw prod. }{ }^{\mathrm{x}} \\
\text { storage }\end{array}$ & Microbiol. & \#1-Room temp. & 0 to $4.4^{\circ} \mathrm{C}$ & $\begin{array}{l}\text { Therm. } \\
\text { recording or } \\
\text { continuous } \\
\text { strip chart }\end{array}$ & Hourly & $\begin{array}{l}\text { Inform maint. } \\
\text { Repair equip. } \\
\text { Evaluate prod. } \\
\text { Reject/release. }\end{array}$ & $\begin{array}{l}\text { Temp. record. } \\
\text { Therm. } \\
\text { calibr. record }\end{array}$ & $\begin{array}{l}\text { Random } \\
\text { samp. } \\
\text { QA audit }\end{array}$ \\
\hline $\begin{array}{l}\text { Trim/core } \\
\text { operation }\end{array}$ & Physical & $\begin{array}{l}\text { \#2-Employee } \\
\text { handling and } \\
\text { visual inspection }\end{array}$ & $\begin{array}{l}\text { No foreign } \\
\text { objects }\end{array}$ & Visual & Continuous & $\begin{array}{l}\text { Remove foreign } \\
\text { object(s). }\end{array}$ & $\begin{array}{l}\text { Incident foreign } \\
\text { object report }\end{array}$ & $\begin{array}{l}\text { Random prod. } \\
\text { samp. QA audit }\end{array}$ \\
\hline Washing & Microbiol. & $\begin{array}{l}\text { \#3-Chlorination, } \\
\text { water pH }\end{array}$ & $\begin{array}{l}\text { Free chlorine: } \\
2-7 \mathrm{mg} \cdot \mathrm{L}^{-1} \text { free } \\
\text { residual after } \\
\text { contact. Total } \\
\text { chlorine: } \mathrm{max} \text {. of } \\
100-150 \mathrm{mg} \cdot \mathrm{L}^{-1} \text {. } \\
\text { pH }=6.0 \text { to } 7.0\end{array}$ & $\begin{array}{l}\text { Test kit or } \\
\text { continuous } \\
\text { strip chart }\end{array}$ & $\begin{array}{l}\text { Three times } \\
\text { per shift }\end{array}$ & $\begin{array}{l}\text { Manually adjust } \\
\text { water chemistry. } \\
\text { Repair system. } \\
\text { Hold prod. from } \\
\text { last correct } \\
\text { reading. Rerun. }\end{array}$ & $\begin{array}{l}\text { Chlorine/pH } \\
\text { records }\end{array}$ & $\begin{array}{l}\text { Random samp. } \\
\text { QA audit. } \\
\text { Bacteria counts }\end{array}$ \\
\hline \multirow[t]{2}{*}{ Packaging } & Microbiol. & $\begin{array}{l}\text { \#4-Prod. } \\
\text { temp. }\end{array}$ & $\begin{array}{l}<4.4^{\circ} \mathrm{C} \\
\text { recording }\end{array}$ & Therm. & Hourly & $\begin{array}{l}\text { Hold prod. } \\
\text { Evaluate. } \\
\text { Reject/release. }\end{array}$ & $\begin{array}{l}\text { Temp. record } \\
\text { Therm. } \\
\text { calibration. } \\
\text { record }\end{array}$ & $\begin{array}{l}\text { Random samp. } \\
\text { QA audit. Track } \\
\text { customer } \\
\text { complaints. }\end{array}$ \\
\hline & Physical & $\begin{array}{l}\text { \#5-Metal } \\
\text { detector }\end{array}$ & No metal & $\begin{array}{l}\text { Calibrate } \\
\text { machine } \\
\text { with metal } \\
\text { sample. }\end{array}$ & Hourly & $\begin{array}{l}\text { Inform maint. } \\
\text { Repair equip. }\end{array}$ & $\begin{array}{l}\text { Metal detector } \\
\text { record. } \\
\text { Hold prod. from } \\
\text { previous correct } \\
\text { reading. Rerun. }\end{array}$ & \\
\hline $\begin{array}{l}\text { Finished } \\
\text { prod. storage }\end{array}$ & Microbiol. & \#6-Prod. temp. & 0 to $4.4^{\circ} \mathrm{C}$ & $\begin{array}{l}\text { Therm. } \\
\text { recording or } \\
\text { continuous } \\
\text { strip chart }\end{array}$ & $\begin{array}{l}\text { Hourly } \\
\text { Evaluate. } \\
\text { Reject/release. }\end{array}$ & $\begin{array}{l}\text { Hold prod. } \\
\text { Therm. } \\
\text { calibration. } \\
\text { record }\end{array}$ & $\begin{array}{l}\text { Temp. } \\
\text { QA audit }\end{array}$ & Random samp. \\
\hline Distribution & Microbiol. & $\begin{array}{l}\text { \#7-Trailer and } \\
\text { prod. temp. }\end{array}$ & $<4.4^{\circ} \mathrm{C}$ & $\begin{array}{l}\text { Therm. } \\
\text { recording or } \\
\text { continuous } \\
\text { strip chart }\end{array}$ & Every load & $\begin{array}{l}\text { Hold prod. } \\
\text { Evaluate. } \\
\text { Reject/release. }\end{array}$ & $\begin{array}{l}\text { Temp. records. } \\
\text { Shipping } \\
\text { records }\end{array}$ & $\begin{array}{l}\text { Random travel } \\
\text { temp. recorder. } \\
\text { QA audit }\end{array}$ \\
\hline
\end{tabular}

${ }^{\mathrm{z}}$ Used with permission from the International Fresh-cut Produce Association.

${ }^{y}$ This HACCP plan can only be effective if prerequisite programs in sanitation and employee good manufacturing practices (GMPs) are implemented and verified. ${ }^{\mathrm{x}}$ Abbreviations: prod. $=$ product; microbiol. = microbiological; maint. $=$ maintenance; therm. $=$ thermometer; equip. $=$ equipment; samp. $=$ sampling; calibr. $=$ calibration; QA = quality assurance.

critical control points, including sanitation programs, water quality management, and strict temperature control during storage, processing, transportation, and retail display, can help reduce the risk of microbial contamination, but cannot eliminate the risk of foodborne pathogens on produce. The use of low temperature as a critical control point has recently been questioned since psychrotrophic organisms such as Listeria monocytogenes can grow at temperatures as low as 5 ${ }^{\circ} \mathrm{C}$ (Beuchat et al., 1986; Steinbruegge et al., 1988).

\section{GOOD AGRICULTURAL PRACTICES FOR FRESH PRODUCE}

To help minimize the risk of foodborne pathogens on fresh produce, guidelines have been developed by industry in cooperation with the FDA. The guidelines focus on risk reduction, not risk elimination, since current technologies cannot ensure elimination of all potential food safety risks associated with fresh produce. Potential microbiological hazards associated with produce include: 1) water; 2) manure; 3) sanitation for workers, and in fields and facilities; and 4) transportation and handling. The following is a synopsis of the guidelines developed by the FDA.

\section{Water quality}

Water quality is extremely important since water is a vehicle for many pathogenic microorganisms (Lopes, 1991). Growers should consider the water quality of all unit operations, including irrigation systems, dump tanks, flumes, precooling operations, and rinsing stations. Water sources should be periodically tested for pathogens, especially if livestock operations are located nearby. Also, a program should be set up to clean and sanitize all equipment in the plant or packing shed that comes in contact with water. Water that contacts produce during cooling and rinsing should be changed daily or more frequently to prevent the risk of cross-contamination. Cooling water that is recycled can become contaminated with spoilage and pathogenic microorganisms and contaminate produce during cooling (Reina et al., 1995). If cooling water cannot be changed on a daily basis, sanitation efficiency may be improved by removal of organic matter and debris by filtration. Chlorinated wash water will generally reduce microbial populations on the surfaces of produce by only 1 to $2 \log$ units (90\% to $99 \%)$. However, the efficacy of chlorine declines as soil residue and organic matter increase in wash water. Failure to maintain adequate chlorine levels in wash water can lead to recontamination of produce (Senter et al., 1985).

It may be advantageous for operators to implement an initial wash treatment to remove the bulk of the field soil on produce, followed by a chlorine wash (100-200 $\mathrm{mg} \cdot \mathrm{L}^{-1}$ for 3-5 $\mathrm{min}$ ) and subsequent rinse with potable water. Automated systems are available that will monitor and adjust chlorine levels and wash water $\mathrm{pH}$ (optimum 6.5 to 7.0 ) to maximize formation of the reactive species of chlorine, the undissociated hyperchlorous acid (HOCL). An alternative technique is being explored that monitors the oxidation-reduction potential (ORP) of process water using probes that measure chlorine activity in millivolts (Suslow, 1997). However, more research is needed to determine the relationship between ORP activity, contact time, and microbial inactivation for different chlorine-based sanitizers. 
Water temperature may also play a role in produce contamination. Immersion of warm tomatoes (Lycopersicon esculentum Mill.) in colder water may create a pressure differential allowing human pathogens such as Salmonella (Zhuang et al., 1995) or postharvest pathogens (Bartz, 1988) on the tomato surface or stem scar or in the water to enter the fruit. Wash water for tomatoes should be chlorinated and $5^{\circ} \mathrm{C}$ warmer than the temperature of the fruit (Showalter, 1993).

\section{Manure handling}

Untreated or improperly treated manure used as fertilizer or as a soil amendment may contaminate produce directly or may passively enter ground or surface water. Growers should identify sources of fecal contamination in their growing operations. Potential sources of contamination, in addition to untreated and improperly treated manure, include composting or manure storage areas, livestock or poultry operations, and high concentrations of wildlife in the growing and harvesting environments. Additionally, windblown dust from feedlots or pastures adjacent to fields or orchards might be identified as a potential source of contamination. It is especially important for produce packers to follow GMPs in order to eliminate nesting birds, rodents, and insects in the packing shed.

To reduce the potential for contamination of fresh produce, when handling manure, growers should follow GAPs, including proper composting methods designed to reduce pathogens present in manure. Manures should be well aged and decomposed prior to field application. Manure slurry should be stored for $60 \mathrm{~d}$ in summer and $90 \mathrm{~d}$ in winter prior to field application (Rangarajan et al., 1999). Information on composting conditions necessary to inactivate pathogens is scarce. Droffner and Brinton (1995) reported that Salmonella and E. coli remained detectable for $59 \mathrm{~d}$ in compost maintained at $60^{\circ} \mathrm{C} ; \mathrm{E}$. coli remained detectable during the curing period for at least $50 \mathrm{~d}$ as temperatures dropped to $40^{\circ} \mathrm{C}$. More research is needed to understand how pathogens respond and adapt to changing environmental conditions during composting, and what active treatments may effectively eliminate pathogens in manure.

To reduce the high risk of contamination from untreated manure, growers should incorporate the manure into the soil prior to planting, or maximize the time between manure application to a field and harvest. Recommendations from the National Organic Standards Board specify that untreated manure should not be applied within 60 $\mathrm{d}$ of harvest of crops intended for human consumption (U.S. Dept. of Agriculture, 1990). However, this is still a questionable practice since E. coli $\mathrm{O} 157: \mathrm{H} 7$ can survive in bovine feces for $70 \mathrm{~d}$ (Wang et al., 1996), and L. monocytogenes can survive in soil at or near initial populations from 8 weeks to several years (Dijkstra, 1975; Watkins and Sleath, 1981). Unfortunately, the survival rate of other pathogens that may contaminate produce in the field under various environmental conditions is unknown.

Growers should identify sources of animal feces that may come into contact with their crop. Domestic animals should be confined and not allowed to graze in fresh produce fields, vineyards, and orchards during the growing season. Control of wild animals in growing areas is difficult, but growers may consider physical barriers such as fences to exclude such animals. If farms used for animal production are located nearby, growers should consider physical barriers, such as ditches, mounds, or grass/sod waterways, to prevent runoff and potential cross-contamination of their crops.

\section{Sanitation for workers, and in fields and facilities}

Workers in the field and packing shed should follow health and hygienic practices (GMPs) as described in the Code of Federal Regulations (1998). Since fecal contamination may play a role in many cases of foodborne illness from produce, steps should be taken to minimize the potential for contact between fecal material and produce. Employees should be educated about basic sanitation and hygienic principles, especially in regard to proper handwashing after use of the rest room. Employees should also learn how to identify signs and symptoms of infectious diseases. In addition to establishing training programs, employers should provide workers with protective clothing and sanitary rest room facilities equipped with toilet paper, soap, potable water and paper towels. Workers with infected wounds should not be allowed to handle fresh produce.

Cross-contamination of produce with foodborne pathogens may occur both before and during harvest because of contact with soils, water, workers, and growing and harvesting equipment. All storage facilities, pallets, bins, totes, and harvesting equipment should be cleaned and sanitized prior to use. Although removal of all mud and soil from produce in the field is impossible, attempts should be made to remove as much as possible prior to transport to the packing shed to avoid contamination with fecal material present in the soil. A sanitation program should be set up for washing and packing lines, cooling systems and storage areas. All equipment should be washed on a daily basis and disinfected with a sanitizing agent.

\section{Transportation}

Transportation is a critical link in maintaining food safety from the farm to the table. To ensure that produce is not contaminated with pathogens during transport, trucks and cartons should be inspected for cleanliness, odors, and filth prior to loading produce. Operators should be aware of prior loads, especially if animal or animal products were transported. Ideally, trucks should be cleaned with potable water and disinfected with a sanitizing agent before hauling fresh produce. Workers involved in loading and unloading produce should be trained to practice proper handwashing techniques. Storage temperature is a critical factor affecting both the quality and safety of fresh produce. Therefore tractor-trailer temperatures during transport of fresh produce should be monitored and documented.

\section{NEW TECHNOLOGIES}

Implementation of GAPs, GMPs, and HACCP will help reduce the risk of microbial contamination of fresh produce, but these safety assurance programs cannot totally eliminate risks. Additional technologies, if required, may be used in combination to achieve a hurdle approach to prevent the growth of pathogenic microorganisms.

\section{Sanitizing agents}

Although chlorine has served as an effective sanitizing agent in the food industry for many years, it has recently come under scrutiny because of formation of undesirable chlorinated by-products (Richardson et al., 1998). Other disadvantages of chlorine are its relative ineffectiveness in water containing high concentrations of organic matter and its sensitivity to $\mathrm{pH}$. Many studies report microbial population reductions to $<1-2 \operatorname{logs}$ when chlorine was used as a sanitizing wash at recommended levels (Brackett, 1987; Sapers et al., 1998; Zhang and Farber, 1996; Zhuang et al., 1995). Pathogens such as $L$. monocytogenes have also shown resistance to treatment with chlorinated wash water as demonstrated on brussels sprouts (Brassica oleracea L., Gemmifera group) (Brackett, 1987). Alternatives to chlorine are needed, which ideally will be more efficacious, produce less disinfection by-products, and be less sensitive to fluctuations in water $\mathrm{pH}$ and high organic matter content.

The use of ozone as a sanitizing agent for food processing has recently been reviewed (Graham, 1997). Ozone destroys microorganisms much faster than does chlorine because of its high oxidation potential, and may be used at much lower concentrations $\left(<1 \mathrm{mg} \cdot \mathrm{L}^{-1}\right)$. It is also less sensitive to temperature and $\mathrm{pH}$ than is chlorine. However, ozone has several disadvantages, including its corrosive nature, phytotoxicity, and ineffectiveness in the presence of organic matter, and concerns regarding worker safety. Ozone is highly effective as a disinfection treatment for water, but its effectiveness is variable when used as a sanitizing wash for fresh produce. Williams et al. (personal communication) reported a 3-log reduction in Pseudomonas putrefaciens in carrot (Daucus carota $\mathrm{L}$.) wastewater treated with $0.25 \mathrm{mg} \cdot \mathrm{L}^{-1}$ ozone, and a $1.11 \mathrm{mg} \cdot \mathrm{L}^{-1}$ ozone wash treatment for broccoli (Brassica oleracea L.) resulted in a 3-log reduction of total aerobic organisms, whereas only a $1-\log$ reduction was obtained with $100 \mathrm{mg} \cdot \mathrm{L}^{-1}$ chlorine (Hampson et al., personal communication). 
However, addition of ozone to dump tank water was ineffective in reducing decay of pears (Pyrus sp.) (Spotts and Cervantes, 1992).

Chlorine dioxide has 2.5 times the oxidizing power of chlorine, is less sensitive to fluctuations in $\mathrm{pH}$, and does not react readily with organic matter (Dychdala, 1991). Promising results have been obtained in studies where chlorine dioxide was used as a wash water treatment. Chlorine dioxide treatment $\left(25 \mathrm{mg} \cdot \mathrm{L}^{-1}\right)$ of cucumber (Cucumis sativas $\mathrm{L}$.) wash water resulted in a 4-log reduction in total plate count, compared with a $<1-\log$ reduction with the same concentration of sodium hypochlorite (Costilow et al., 1984). A $1.3 \mathrm{mg} \cdot \mathrm{L}^{-1}$ chlorine dioxide treatment resulted in 2-6 log cycle reductions in bacteria present in cucumber wash water (Reina et al., 1995). Low concentrations of chlorine dioxide (3-5 $\left.\mathrm{mg} \cdot \mathrm{L}^{-1}\right)$ also effectively controlled fungal decay spores in pear dump tank water (Roberts and Reymond, 1994). However, chlorine dioxide is less effective when used as a sanitizing wash for fresh produce. Less than a 1-log reduction in total plate count was obtained when cucumber fruit were washed with $25 \mathrm{mg} \cdot \mathrm{L}^{-1}$ chlorine dioxide (Costilow et al., 1984), and bacterial populations on cucumber fruit were relatively unaffected by treatment with a wash water containing $5.1 \mathrm{mg} \cdot \mathrm{L}^{-1}$ chlorine dioxide (Reina et al., 1995). Chlorine dioxide is currently approved as a wash treatment for uncut produce, and is being reviewed for approval as a wash treatment for fresh-cut produce.

Trisodium phosphate (TSP) has been investigated as an antimicrobial wash water treatment for produce. A 120 -s wash with $12 \%$ TSP resulted in a 4-log reduction of Salmonella montevideo on the surfaces of tomatoes (Zhuang and Beuchat, 1996), while a 2.5-log reduction of E. coli was reported for apples washed with a TSP solution heated to $50{ }^{\circ} \mathrm{C}$ (Sapers et al., 1998). However, a 2\% TSP wash treatment was ineffective in reducing the population of $L$. monocytogenes on lettuce (Lactuca sativa L.) (Zhang and Farber, 1996). Pathogens also vary in their resistance to TSP, with $L$. monocytogenes being resistant, and $E$. coli O157:H7 being sensitive (Somers et al., 1994).

Hydrogen peroxide $\left(\mathrm{H}_{2} \mathrm{O}_{2}\right)$ has shown promise as a postharvest treatment for preventing decay and also as a disinfection treatment for fresh and fresh-cut produce (Sapers and Simmons, 1998). A 5\% $\mathrm{H}_{2} \mathrm{O}_{2}$ wash treatment resulted in a 3.4-log reduction of E. coli (ATCC 25922) on 'Golden Delicious' apple halves compared with a 2-log reduction obtained with $200 \mathrm{mg} \cdot \mathrm{L}^{-1}$ chlorine (Sapers, 1998). Greater than a 4-log reduction was obtained when a $5 \% \mathrm{H}_{2} \mathrm{O}_{2}$ treatment was combined with a $2 \%$ acidic surfactant at $50{ }^{\circ} \mathrm{C}$. However, the application of $\mathrm{H}_{2} \mathrm{O}_{2}$ as a sanitizing wash is limited because of the phytotoxic response observed in sensitive commodities such as anthocyanin-containing small fruits [strawberries (Fragaria $\times$ ananassa Duch.), blueberries (Vaccinium sp.) and blackberries (Rubus sp.)] and mushrooms, and the necessity to remove residual peroxide from the surface of the produce.

Promising results have been obtained using peracetic acid as an antimicrobial treatment. Peracetic acid and water are formed in an equilibrium reaction of acetic acid and hydrogen peroxide, using catalysts. Advantages of peracetic acid include no undesirable reaction by-products, strong oxidation potential, and, more importantly, less sensitivity to high organic matter and soil residue. Peracetic acid was reported to be effective in reducing microbial counts in produce wash water and on fruit surfaces (Hei, 1998). It is approved by FDA for whole or cut fruits and vegetables either in water systems or as a direct application.

Hot water washes have been effective in reducing populations of postharvest decay organisms on some commodities, and may show promise in eliminating human pathogenic microorganisms from commodity surfaces (Fallik, 1998). In this system, produce is first washed with potable water, then placed on moving brushes and disinfected with recycled water at 50 to $75^{\circ} \mathrm{C}$ for 5 to $30 \mathrm{~s}$. Short-term exposure of produce to temperatures approaching those used for pasteurization does not affect quality. This technology has been commercialized in Israel for various horticultural crops.

Many of the studies investigating the effectiveness of new sanitizing agents demonstrate that some new products are effective in reducing pathogens in waste water, but are relatively ineffective when used as a wash or rinse treatment for fresh or fresh-cut produce. This ineffectiveness may be due to the rapid buildup of soil residue and organic matter in the wash water, or to the inability of the agents to contact microorganisms on the surfaces of fruits and vegetables. Horticultural products have hydrophobic lipid coatings, and many natural openings, including stomata, lenticels, and trichomes, which can harbor spoilage and pathogenic microorganisms (Adams et al., 1989).

Formation of biofilms by microorganisms may also contribute to the ineffectiveness of sanitizing agents. A biofilm consists of microbial cells that are immobilized on a surface and frequently imbedded in an organic matrix of microbial origin. Biofilms are variable in nature and usually contain several species of organisms. Several pathogenic microorganisms form biofilms on surfaces of processing equipment and poultry products (Zottola, 1994), and are reported to be $150-3000$ times more resistant to chlorine once such biofilms are formed (LeChevallier et al., 1988). Use of surfactant and detergent treatments prior to sanitizing washes may increase dislodgment and destruction of pathogenic microorganisms. Chemical cleaners are more effective than sanitizers in removing biofilms. For example, L. monocytogenes was more effectively removed from biofilms on stainless steel and plastic surfaces by chemical cleaners than by sanitizing agents (Krysinski et al., 1992). The principles of action of cleaning detergents and sanitizers on biofilms are illustrated in Figure 1. When a sanitizer is used alone, the chemical is rapidly inactivated by the matrix of the biofilm and is ineffective in reaching and destroying the protected microorganisms (Fig. 1A). However, when the soil-covered biofilm is first treated with a detergent, the soil and biofilm matrix is dislodged and rinsed away (Fig. 1B). The exposed microorganisms are then
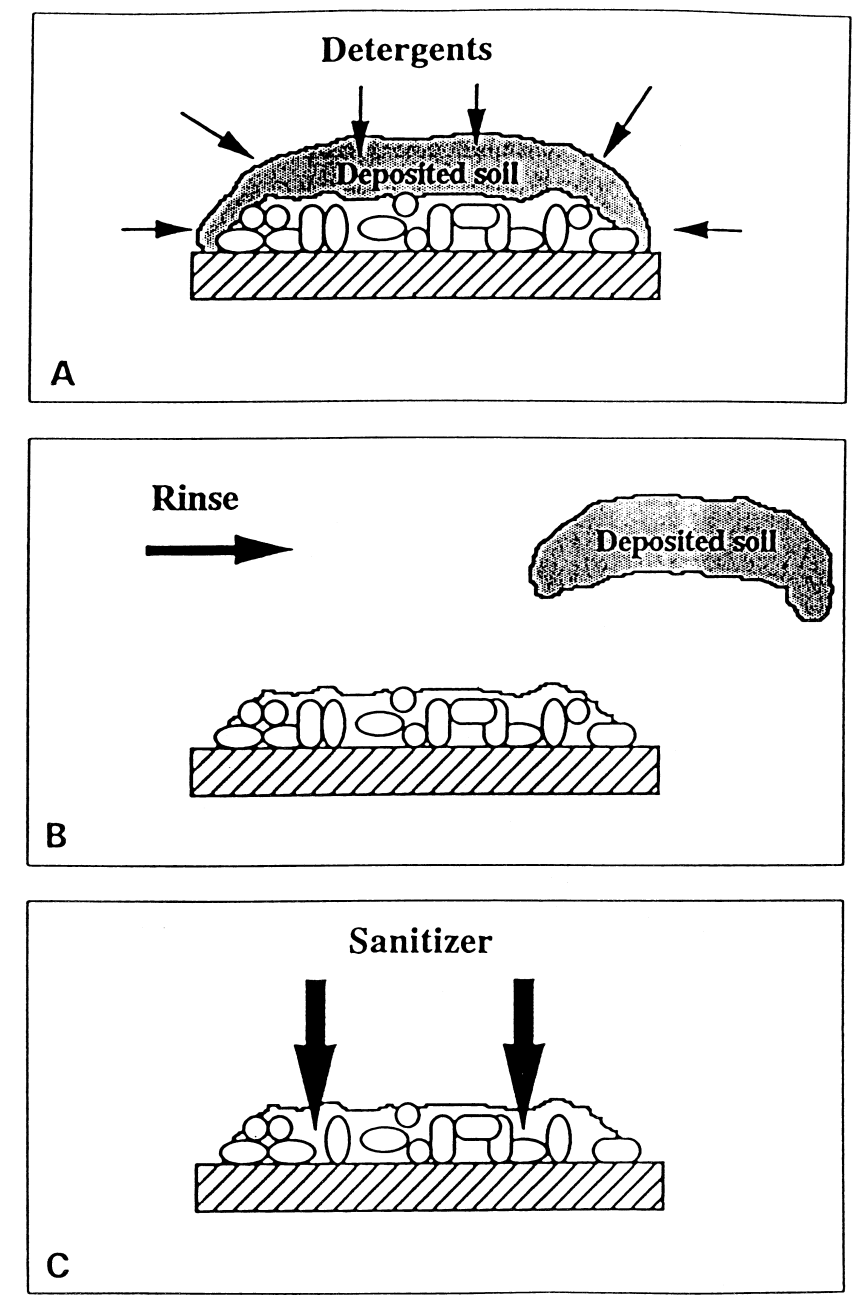

Fig. 1. Cleaning and sanitizing process. (A) Detergent (arrow) solubilizes the fat, carbohydrate, protein, and minerals constituting the deposited soil. (B) Rinsing with detergent carries away deposited soil exposing microorganisms in a biofilm. (C) Sanitizer (large arrow) penetrates biofilm to inactivate microorganisms (from Zottola, 1994). 
much more susceptible to the sanitizing agent (Fig. 1C). Unfortunately, attachment of pathogenic microorganisms via biofilms on fresh and fresh-cut fruits and vegetables has not been studied. Adams et al. (1989) demonstrated that addition of a surfactant to hypochlorite reduced microbial numbers by $99.6 \%$, but impaired sensory quality of prepared salads. Acidic surfactant formulations also showed promise in reducing E. coli on apple halves (Sapers et al., 1998). Future studies should focus on understanding how pathogenic microorganisms attach to fruit and vegetable surfaces, and combinations of detergents and sanitizers should then be tested to determine their efficacy in pathogen removal and destruction, without impairment of sensory quality.

\section{Low-dose gamma-ionizing radiation}

Fresh fruits and vegetables may be treated with ionizing radiation with doses up to $1 \mathrm{kGy}$. Low-dose irradiation has been used to extend the shelf-life of minimally processed, refrigerated pico de gallo (Howard et al., 1995), shredded carrots (Chervin and Boisseau, 1994), shrink-wrapped sweet corn (Zea mays L.) (Deak et al., 1987), bell pepper (Capsicum annuum L.) slices and diced carrots (Farkas et al., 1997), without impairment of sensory quality. This treatment was recently used in conjunction with chlorine rinses and modified atmosphere storage to reduce microbial counts on fresh-cut iceberg lettuce (Hagenmaier and Baker, 1997), and shredded carrots (Hagenmaier and Baker, 1998). However, a potential hazard associated with this treatment is that competitive microflora may be destroyed, allowing pathogens such as Clostridium botulinum and L. monocytogenes to grow and proliferate, especially if the product is temperature abused (exposed to ambient temperature) and anaerobic conditions develop in modified atmospheres. Unfortunately, doses much greater than $1 \mathrm{kGy}$ are required to destroy bacterial endospores, molds, yeasts, and viruses (Brackett, 1994), and these high doses are known to cause softening and off-odors in many horticultural crops (Kader, 1986). However, the treatment may be effective for eliminating pathogenic microorganisms from the surfaces of produce. Farkas et al. (1997) reported that a $1-\mathrm{kGy}$ treatment resulted in a 4-log reduction of L. monocytogenes on the surfaces of sliced bell peppers. More research is needed to determine if low-dose irradiation can reduce or eliminate additional foodborne pathogens that grow on fresh and fresh-cut produce, without impairment of sensory quality.

\section{Pulsed light}

Food applications for pulsed-light treatments have been reviewed (Dunn, 1996; Hoover, 1997). This technology is based on a rapid, intense, magnified flash of light or electrical energy derived from a capacitor (Dunn, 1996). The emitted light pulse is comprised of $\approx 25 \%$ ultraviolet, $45 \%$ visible, and $30 \%$ infrared radiation (light). This treatment is most effective when the pulsed light can penetrate food surfaces or transparent media such as packages. Although shelf life extension for fresh fruits and vegetables has been reported (Dunn, 1996), the effectiveness of the treatment is limited because of the irregular nature of the fruit and vegetable surfaces, and the microenvironments on produce surfaces that can harbor microbes. Pulsed or UV light treatments have shown promise in destroying microorganisms in fresh juices, without impairment of sensory quality (Dunn, 1996).

\section{Edible coatings}

Edible coatings can improve the sensory quality of fresh and freshcut produce, primarily through retardation of moisture loss. Their use to improve the quality of foods and their chemistry have recently been reviewed (Baldwin et al., 1995, 1997; Krochta and DeMulder-Johnston, 1997). A novel application for edible coatings could be as a carrier of antimicrobial agents to retard spoilage and the growth of pathogenic microbes on the surfaces of fresh and fresh-cut produce during storage and distribution (Baldwin et al., 1995). A hydroxypropyl methylcellulose coating in ethanol effectively reduced the number of viable cells of Salmonella montevideo on the surface of tomatoes, but was less effective in retarding pathogen growth in core tissue (Zhuang et al.,
1996). Incorporation of other natural antimicrobial agents, such as organic acids (Beuchat and Golden, 1989); flavor volatiles, such as allyl isothiocyanate (Isshiki et al., 1992) and methyl jasmonate (Buta and Moline, 1998); and bacteriocins into edible coatings or slowrelease delivery systems may be effective in preventing growth of pathogenic microorganisms. More research is needed to determine how, during storage in modified atmospheres, foodborne pathogens react and adapt to edible coatings containing antimicrobial agents, and to changes in temperature.

The adaptation of E. coli $\mathrm{O} 157 \mathrm{H} 7$ and Salmonella sp. to tolerate high acid conditions in nonpasteurized apple (Miller and Kaspar, 1994; Zhao et al., 1993), and orange [Citrus sinensis (L.) Osbeck] juice (Winniczuk and Parish, 1997) illustrates that precautions must be taken when using acidulants to control spoilage and pathogenic microorganisms on produce.

\section{Biocontrol agents}

The use of lactic acid bacteria (LAB) to control pathogen growth in refrigerated foods has received attention (Breidt and Fleming, 1997; Gombas, 1989). Such species can produce a variety of metabolites, including lactic and acetic acids, hydrogen peroxide, and bacteriocins, which are inhibitory to competing bacteria, including psychrotrophic pathogens (DeVuyst and Vandame, 1994; Vandenberg, 1993). Theoretically, the LAB applied to the surfaces of fresh-cut produce should proliferate and prevent the growth of pathogenic micoorganisms by competitive inhibition, especially during prolonged storage or temperature abuse (Breidt and Fleming, 1997). Selected strains of psychrotrophic LAB isolated from fresh salad vegetables were used in challenge studies to prevent the growth of Aeromonas hydrophila, Listeria monocytogenes, Salmonella typhimurium, and Staphyloccocus aureus inoculated on salad products (Vescovo et al., 1996). The LAB cultures effectively prevented pathogen growth after $6 \mathrm{~d}$ of storage. Cultures of LAB have also been used to control L. monocytogenes in brined, nonacidified, refrigerated pickle products (Breidt and Fleming, 1997; Romick, 1994) and cucumber juice (Breidt and Fleming, 1997). Sanitizing agents should be used in conjunction with biocontrol agents to reduce the initial microbial population on fresh-cut produce and to ensure the predominance of the growth of LAB on the product surface. Factors affecting the competitive growth of $\mathrm{LAB}$ on fresh-cut produce need to be studied, since a significant variation in natural microflora exists among fruits and vegetables (Nguyen-the and Carlin, 1994).

\section{Hurdle technology}

Hurdle technology utilizes a combination of existing and novel preservation techniques to establish a series of preservation hurdles that microorganisms are unable to overcome (Leistner and Gorris, 1995). The use of hurdle technology to preserve refrigerated foods has recently been reviewed (Ahvenainen, 1996; Leistner and Gorris, 1995; Tapia de Daza et al., 1996). Many of the technologies previously discussed may be used in combination in a hurdle approach to control pathogen growth on fresh and fresh-cut produce. Potential hurdle treatments include sanitizing agents, low-dose ionizing radiation, edible coatings containing antimicrobial agents, biocontrol agents, and modified-atmosphere packaging. An example of a hurdle approach is illustrated in Figure 2. Reducing the initial microbial load of fresh and fresh-cut produce through implementation of GAPs and the use of sanitizing agents is critical prior to the application of additional hurdle treatments. If initial microbial counts are too high, the microorganisms may scale the hurdles and proliferate during prolonged storage. This is especially hazardous if pathogenic microorganisms survive the preservation hurdles and outgrow competitive epiphytic microflora during storage or temperature abuse. Potential proliferation of pathogenic microorganisms at the expense of spoilage microorganisms is a concern associated with all new technologies currently being explored. Survival of spoilage organisms is a necessary and critical event to signal the end of the product's shelf life. More research is needed to ensure that new technologies do not create an environment favorable for growth of pathogenic microorganisms on fresh and fresh-cut produce. 


\section{Hurdle Approach for Pre-Cut Produce Scenario 1}

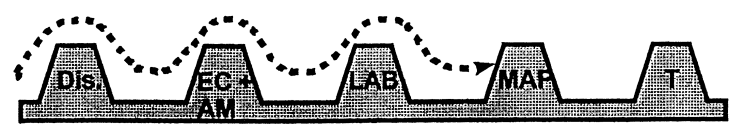

Low Initial Microbial Load, Good Temperature Control

\section{Hurdle Approach for Pre-Cut Produce Scenario 2}

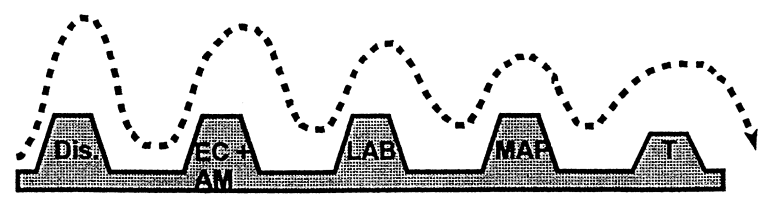

High Initial Microbial Load, Poor Temperature Control

Fig. 2. Hurdle approach for controlling microorganisms on pre-cut produce. Dis. $=$ disinfectant $; \mathrm{EC}+\mathrm{AM}=$ edible coating containing antimicrobial agent; $\mathrm{LAB}=$ lactic acid bacteria; $\mathrm{MAP}=$ modified atmosphere package; and $\mathrm{T}=$ temperature control.

\section{FUTURE CONSIDERATIONS FOR SAFE PRODUCE}

To prevent contamination of fresh produce by pathogenic microorganisms, we need to look at the whole food chain, from the field to the consumers plate, to identify important control points, and establish risk prevention steps. To achieve this goal, implementation and documentation of GAPs in growing, harvesting, handling, and transporting produce will be necessary, as well as strict adherence to GMPs in the packaging shed or processing plant. A major effort should be undertaken to train all individuals that come into contact with produce, including growers, farm workers, plant employees, shippers, distributors, retailers, and consumers, on the importance of personal hygiene and basic food safety principles. New washing and disinfection technologies are emerging and will eventually become part of GAP and HACCP programs. New methods for rapid pathogen detection are being developed that will help scientists identify the sources of pathogen contamination in produce operations, and assist in development of effective traceback systems to link outbreaks of foodborne illness to specific sites. Microbial risk assessment will become an important tool to insure that equivalency of food safety systems is achieved in countries exporting produce to the United States. Improvements in temperature control, especially at supermarkets, will improve the safety and quality of fresh and fresh-cut produce. Strict temperature control of fresh-cut products may require the use of enclosed refrigeration units. Use of time-temperature indicators on fresh-cut packages will help identify sites where temperature abuse occurs throughout their cold storage. Since there are many weak links in the food production chain where pathogens may contaminate fresh produce, and removal of pathogens from the surfaces of produce is difficult, prevention will require collaborative efforts by academia, industry, and public health agencies.

\section{Literature Cited}

Adams, M.R., A.D. Hartley, and L.J. Cox. 1989. Factors affecting the efficacy of washing procedures used in the production of prepared salads. Food Microbiol. 6:69-77.

Ahvenainen, R. 1996. New approaches in improving the shelf life of minimally processed fruit and vegetables. Trends Food Sci. Technol. 7:179-187.

Baldwin, E.A., M. Nisperos-Carriedo, and R.A. Baker. 1995. Use of edible coatings to preserve quality of lightly (and slightly) processed products. Crit. Rev. Food Sci. Nutr. 35:509-524.

Baldwin, E.A., M.O. Nisperos, R.D. Hagenmaier, and R.A. Baker. 1997. Use of lipids in coatings for food products. Food Technol. 51:56-64.

Bartz, J.A. 1988. Potential for postharvest disease in tomato fruit infiltrated with chlorinated water. Plant Dis. 72:9-13.

Besser, R.E., S.M. Lett, J.T. Weber, M.P. Doyle, T.J. Barret, J.G. Wells, and P.M. Griffin. 1993. An outbreak of diarrhea and hemolytic uremic syndrome from Escherichia coli 0157:H7 in fresh-pressed apple cider. J. Amer. Med. Assoc. 269:2217-2220.

Beuchat, L.R., R.E. Brackett, D.Y. Hao, and D.E. Conner. 1986. Growth and thermal inactivation of Listeria monocytogenes in cabbage and cabbage juice. Can. J. Microbiol. 32:791-795.

Beuchat, L.R. 1995. Pathogenic microorganisms associated with fresh produce. J. Food Protection 59: 204-216.

Beuchat, L.R. and D.A. Golden. 1989. Antimicrobials occurring naturally in foods. Food Technol. 43:135-142.

Beuchat, L.R. and J. Hoon-Ryu. 1997. Produce handling and processing practices. Emerg. Infect. Dis. 3:459-464.

Brackett, R.E. 1987. Antimicrobial effect of chlorine on Listeria monocytogenes. J. Food Protection 50:999-1003.

Brackett, R.E. 1994. Microbiological spoilage and pathogens in minimally processed refrigerated fruits and vegetables, p. 269-312. In: R. Wiley (ed.). Minimally processed refrigerated fruits and vegetables. Chapman and Hall, New York.

Breidt, F. and H.P. Fleming. 1997. Use of lactic acid bacteria to improve the safety of minimally processed fruits and vegetables. Food Technol. 51:44 51.

Buta, J.G. and H.E. Moline. 1998. Methyl jasmonate extends shelf life and reduces microbial contamination of fresh-cut celery and peppers. J. Agr. Food Chem. 46:1253-1256.

Chervin, C. and Boisseau, P. 1994. Quality maintenance of "ready-to-eat" shredded carrots by gamma irradiation. J. Food Sci. 59:359-361, 365.

Code of Federal Regulations. 1998. Title 21, part 110.10. Office of the Federal Register Natl. Archives and Records Admin., U.S. Govt. Printing Office, Washington, D.C.

Corlett, D.A. Jr. 1998. HACCP user's guide. Aspen Publ., Gaithersburg, Md.

Costilow, R., M.A. Uebersax, and P.J. Ward. 1984. Use of chlorine dioxide for controlling microorganisms during the handling and storage of fresh cucumbers. J. Food Sci. 49:396-401.

Deak, T., E.K. Heaton, Y.C. Hung, and L.R. Beuchat. 1987. Extending the shelf life of fresh sweet corn by shrink-wrapping, refrigeration and irradiation. J. Food Sci. 52:1625-1631.

DeVuyst, L. and E.J. Vandamme. 1994. Antimicrobial potential of lactic acid bacteria, p. 91-142. In: L. DeVuyst and E.J. Vandamme (eds.). Bacteriocins of lactic acid bacteria. Blackie Academic and Professional, London.

Dijkstra, R.G. 1975. Recent experiences of the survival times of Listeria bacteria in suspension of brain, tissue, silage, faeces and in milk, p. 71. In: M. Woodbine (ed.). Problems of listeriosis. Leicester Univ. Press, Surrey, U.K.

Droffner, M.L. and W.F. Brinton. 1995. Survival of E. coli and Salmonella populations in aerobic thermophilic composts as measured with DNA gene probes. Zentralblatt fur Hygiene 197:387-397.

Dunn, J. 1996. Pulsed light and pulsed electric field for foods and eggs. Poultry Sci. 75:1133-1136.

Dychdala, G.R. 1991. Chlorine and chlorine compounds. p. 131-151. In: S. Block (ed.). Disinfection, sterilization and preservation. Lea and Febiger Press, Philadelphia.

Fallik, E. 1998. A unique method for simultaneously cleaning and disinfecting agricultural fresh produce using a hot water wash and brushes. Abstract $65-$ 6, Annu. Mtg. Inst. Food Technol., Atlanta.

Farkas, J., T. Saray, C. Mohacsi-Farkas, K. Horti, and E. Andrassy. 1997. Effects of low-dose gamma radiation on shelf-life and microbiological safety of pre-cut/prepared vegetables. Adv. Food Sci. 19:111-119.

Gombas, D.E. 1989. Biological competition as a preserving mechanism. J. Food Safety 10:107-117.

Graham, D.M. 1997. Use of ozone for food processing. Food Technol. 51:72-75.

Hagenmaier, R.D. and R.A. Baker. 1997. Low-dose irradiation of cut iceberg lettuce in modified atmosphere packaging. J. Agr. Food Chem. 45:28642868.

Hagenmaier, R.D. and R.A. Baker. 1998. Microbial population of shredded 
carrot in modified atmosphere packaging as related to irradiation treatment. J. Food Sci. 63:162-164.

Hei, R.D. 1998. Peracetic acid applications to vegetable and fruit flume transport waters improved storage stability, and yielded superior reduction of microbial contaminants during processing. Abstract 65-3, Annu. Mtg. Inst. Food Technol., Atlanta, Ga.

Hoover, D.H. 1997. Minimally processed fruits and vegetables: Reducing microbial load by nonthermal physical treatments. Food Technol. 51:66-71.

Howard, L.R., G.H. Miller, Jr., and A.B. Wagner. 1995. Microbiological, chemical and sensory changes in irradiated pico de gallo. J. Food Sci. 60:461-464.

Isshiki, K., K. Tokuoka, R. Mori, and S. Chiba. 1992. Preliminary examination of allyl isothiocyanate vapor for food preservation. Biosci. Biotech. Biochem. 56:1476-1477.

Itoh, Y., Y. Sugita-Konishi, F. Kasuga, M. Iwaki, Y. Hara-Kudo, N. Saito, Y. Noguchi, H. Konuma, and S. Kumagai. 1998. Enterohemorrhagic Escherichia coli O157:H7 present in radish sprouts. Appl. Environ. Microbiol. 64:1532-1535.

Jaquette, C. B., L.R. Beuchat, and B.E. Mahon. 1996. Efficacy of chlorine and heat treatment in killing Salmonella stanley inoculated onto alfalfa seeds and growth and survival of the pathogen during sprouting and storage. Appl. Environ. Microbiol. 62:2212-2215.

Kader, A.A. 1986. Potential applications of ionizing radiation in postharvest handling of fresh fruits and vegetables. Food Technol. 40:117-121.

Krochta, J.M. and C. DeMulder-Johnston. 1997. Edible and biodegradable polymer films: Challenges and opportunities. Food Technol. 51:61-74.

Krysinski, E.P., L.J. Brown, and T.J. Marchisello. 1992. Effect of cleaners and sanitizers on Listeria monocytogenes attached to product contact surfaces. J. Food Protection 55:246-251.

LeChevallier, M.W., C.D. Cawthon, and R.G. Lee. 1988. Inactivation of biofilm bacteria. Appl. Environ. Microbiol. 54:2492-2499.

Leistner, L. and L.G.M. Gorris. 1995. Food preservation by hurdle technology. Trends Food Sci. Technol. 61:41-46.

Lopes, J.A. 1991. Food and water infective microorganisms, p. 773-790. In: S. Block (ed.). Disinfection, sterilization and preservation. Lea and Febiger Press, Philadelphia.

Miller, L.G. and C.W. Kaspar. 1994. Escherichia coli O157H7 acid tolerance and survival in apple cider. J. Food Protection 57:460-464.

Moberg, L. 1989. Good manufacturing practices for refrigerated foods. J. Food Protection 52:363-367.

National Advisory Committee on Microbiological Criteria for Foods. 1998. Hazard analysis and critical control point principles and application guidelines. J. Food Protection 61:762-775.

Nguyen-the, C. and F. Carlin. 1994. The microbiology of minimally processed fresh fruits and vegetables. Crit. Rev. Food Sci. Technol. 34:371-401.

O’Mahoney, M.J., B. Cowden, D. Smyth, M. Lynch, B. Hall, E.L. Rowe, E.L. Teare, R.E. Tettmar, A.M. Rampling, M. Coles, R.J. Gilbert, E. Kingcott, and C.L.R. Bartlett. 1990. An outbreak of Salmonella saint-paul infection associated with bean sprouts. Epidemiol. Infect. 104:229-235.

Rangarajan, A., M. Pritts and S. Reiners. 1999. Food safety starts on the farm. Cornell Coop. Ext. Serv., Ithaca, N.Y.

Reina, L.D., H.P. Fleming, and E.G. Humphries. 1995. Microbiological control of cucumber hydrocooling water with chlorine dioxide. J. Food Protection 58:541-546.

Richardson, S.D., A.D. Thruston, Jr., T.V. Caughran, T.W. Collete, K.S. Patterson, and B.W. Lykins, Jr. 1998. Chemical by-products of chlorine and alternative disinfectants. Food Technol. 52:58-61.

Roberts, R.G. and S.T. Reymond. 1994. Chlorine dioxide for reduction of postharvest pathogen inoculum during handling of tree fruits. Appl. Environ. Microbiol. 60:2864-2868.

Romick, T.L. 1994. Biocontrol of Listeria monocytogenes, a psychrotrophic pathogen model, in low salt, non-acidified, refrigerated vegetable products. PhD Diss., North Carolina State Univ., Raleigh.

Sapers, G.M. 1998. New technologies for safer produce: Chemical-based treatments and decontamination by washing. NCFST/IFT Symp., Fresh fruits and vegetables: Food safety challenges. Chicago.

Sapers, G.M., R.L. Miller, and A.M. Mattrazzo. 1998. Efficacy of sanitizing agents in inactivating Escherichia coli in cider apples. Abstract 56-2, Annu.
Mtg. Inst. Food Technol., Atlanta.

Sapers, G.M. and G.F. Simmons. 1998. Hydrogen peroxide disinfection of minimally processed fruits and vegetables. Food Technol. 52:48-52.

Senter, S.D., N.A. Cox, J.S. Bailey, and W.R. Forbus Jr. 1985. Microbiological changes in fresh market tomatoes during packing operations. J. Food Sci. 50:254-255.

Showalter, R.K. 1993. Postharvest water intake and decay of tomatoes. HortTechnology 3:97-98.

Somers, G.F., J.L. Schoeni, S. John, and D.A. Margosan. 1994. Effect of trisodium phosphate on biofilm and planktonic cells of Campylobacter jejuni, Escherichia coli O157:H7, Listeria monocytogenes and Salmonella typhimurium. Intl. J. Food Microbiol. 22:269-276.

Spotts, R.A. and L.A. Cervantes. 1992. Effect of ozonated water on postharvest pathogens of pear in laboratory and packinghouse tests. Plant Dis. 76:256259.

Steinbruegge, E.G., R.B. Maxcy, and M.B. Liewen. 1988. Fate of Listeria monocytogenes on ready-to-serve lettuce. J. Food Protection 51:596-599.

Stevenson, K.E. and D.T. Bernard (eds.). 1995. HACCP-Establishing hazard analysis critical control points programs: A workshop manual. Food Processors Inst., Washington, D.C.

Suslow, T.S. 1997. Postharvest chlorination: Basic properties and key points for effective disinfection. Univ. California, Div. of Agr. and Natural Resources, Davis. Publ. 8003.

Tapia-de Daza, M.S., S.M. Alzamora, and J.W. Chanes. 1996. Combination of preservation factors applied to minimal processing of foods. Crit. Rev. Food Sci. Nutr. 36:629-659.

Tauxe, R., H. Kruse, C. Hedberg, M. Potter, J. Madden, and K. Wachsmuth. 1997. Microbial hazards and emerging issues associated with produce: A preliminary report to the national advisory committee on microbiologic criteria for foods. J. Food Protection 60:1400-1408.

U.S. Dept. of Agriculture. 1990. Federal Organic Foods Protection Act, Section 6513 Organic Plan. Washington, D.C.

U.S. Food and Drug Administration. 1998. Guide to minimize microbial food safety hazards for fresh fruits and vegetables. U.S. Dept. Health and Human Serv., Food and Drug Admin., Center for Food Safety and Applied Nutr., Washington, D.C.

Vandenberg, P.A. 1993. Lactic acid bacteria, their metabolic products and interference with microbial growth. FEMS Microbiol. Rev. 12:221-238.

Vescovo, M., S. Torriani, C. Orsi, F. Macchiarolo, and G. Scolari. 1996. Application of antimicrobial-producing lactic acid bacteria to control pathogens in ready-to-use vegetables. J. Appl. Bacteriol. 81:113-119.

Wang, G., T. Zhao, and M.P. Doyle. 1996. Fate of enterohemorrhagic Escherichia coli O157:H7 in bovine feces. Appl. Env. Microbiol. 62:2567-2570.

Watkins, J. and K.P. Sleath. 1981. Isolation and enumeration of Listeria monocytogenes from sewage, sewage sludge, and river water. J. Appl. Bacteriol. 50:1-9.

Winniczuk, P.P. and M.E. Parish. 1997. Minimum inhibitory concentrations of antimicrobials against micro-organisms related to citrus juice. Food Microbiol. 14:373-381.

Zagory, D. 1996. Food safety guidelines for the fresh-cut produce industry, 3rd ed. Intl. Fresh-cut Produce Assoc., Alexandria, Va.

Zhang, S. and J.M. Farber. 1996. The effects of various disinfectants against Listeria monocytogenes on fresh-cut vegetables. Food Microbiol. 13:311321.

Zhao, T., M.P. Doyle, and R.E. Besser. 1993. Fate of enterohemorrhagic Escherichia coli O157:H7 in apple cider with and without preservatives. Appl. Environ. Microbiol. 59:2526-2530.

Zhuang, R.Y. and L.R. Beuchat. 1996. Effectiveness of trisodium phosphate for killing Salmonella montevideo on tomatoes. Lett. Appl. Microbiol. 22:97-100.

Zhuang, R.Y., L.R. Beuchat, and F.J. Angulo. 1995. Fate of Salmonella montevideo on and in raw tomatoes as affected by temperature and treatment with chlorine. Appl. Environ. Microbiol. 61:2127-2131.

Zhuang, R., L.R. Beuchat, M.S. Chinnan, R.L. Shewfelt, and Y.W. Huang. 1996. Inactivation of Salmonella montevideo on tomatoes by applying cellulose-based edible films. J. Food Protection 59:808-812.

Zottola, E.A. 1994. Microbial attachment and biofilm formation: A new problem for the industry? Food Technol. 48:107-114. 